\title{
FUTURE DEVELOPMENT OF FORMER PULA NAVAL FORTRESS
}

\author{
DOI: 10.18485/arh_pt.2020.7.ch39
}

\begin{abstract}
_ Lea Petrović Krajnik
PhD, Assistant Professor, University of Zagreb, Faculty of Architecture, Kačićeva 26, 10000 Zagreb, Croatia, lea.petrovic@arhitekt.hr
\end{abstract}

\section{Ivan Mlinar \\ PhD, Associate Professor, University of Zagreb, Faculty of Architecture, Kačićeva 26, 10000 Zagreb, Croatia, ivan.mlinar@arhitekt.hr}

\section{- Damir Krajnik \\ PhD, Full Professor, University of Zagreb, Faculty of Architecture, Kačićeva 26, 10000 Zagreb, Croatia, damir.krajnik@arhitekt.hr}

\begin{abstract}
Pula is an Istrian town with a number of important historical sites, historical buildings and historical architectural structures and systems which had been built since the prehistoric times. They testify about the culture of living, the architectural heritage and the strategic importance of the Istrian peninsula. The former Austrian Navy had the main naval base in Pula, as the core of Pula's fortification system stretching from Rovinj to Labin. The Austrian naval fortress Pula is the system that embraces the most significant and abandoned military buildings in the area of Pula built in the period from 1813 to 1918. The system of the former naval fortress Pula is part of the recent Pula architectural heritage that needs to be properly integrated into the strategy of the future development of the city and its region. The future of the former naval fortress Pula can be ensured by integral considering and emphasising its potential, as well as its quality and appropriate functional conversion, with the protection, restoration, preservation and presentation of all important urban and architectural features. By highlighting the image, identity and quality of the Pula naval fortress its further decay can be prevented, as well as encouraged its renewal, ensured maintenance and provided eventual additional income.
\end{abstract}

KEYWORDS _ Pula, former naval fortress, built heritage, integration

\section{INTRODUCTION}

Pula is an Istrian town with a number of important historical sites, historical buildings and historical architectural structures and systems which had been built since the prehistoric times. (Regan, Nadilo: 285) Through the history, due to the strategic importance of the Pula area, the fortifications have been built by the Histrians, the Romans, the Venetian Republic and Austria (Milić, 1994: 254; Milić, 1995: 62) as well as Italy, Germany and Yugoslavia.

The Pula area is extremely rich in architectural heritage, consisting of numerous examples of fortifications from the period of the Austrian Empire (1806 - 1867) and the Austro-Hungarian Monarchy (1867 - 1918), which were built in system of the Austrian Maritime Fortress Pula in the 19th and early 20th centuries. The intense development of the city and the construction of the Pula Maritime 
Fortress was stimulated by the official proclamation of Pula for the main naval base of the Austrian Empire in 1853. (Marković, 2006: 219; Trogrlić, Stepanić, 2007: 19) The fortifications of the Naval Fortress Pula, built up to 1918 , have lost their defensive significance in the mid-20th century. Today they are completely out of function, unmaintained and damaged by natural and human activities. Despite the lack of maintenance and decline, the fortifications of the Naval Fortress Pula are, as historical buildings, part of the layered architectural heritage of exceptional cultural significance. Besides they bear witness to the periods of military technology development and defence strategy and form an integral part of the image, identity and quality of the Pula area, Istria and Croatia.

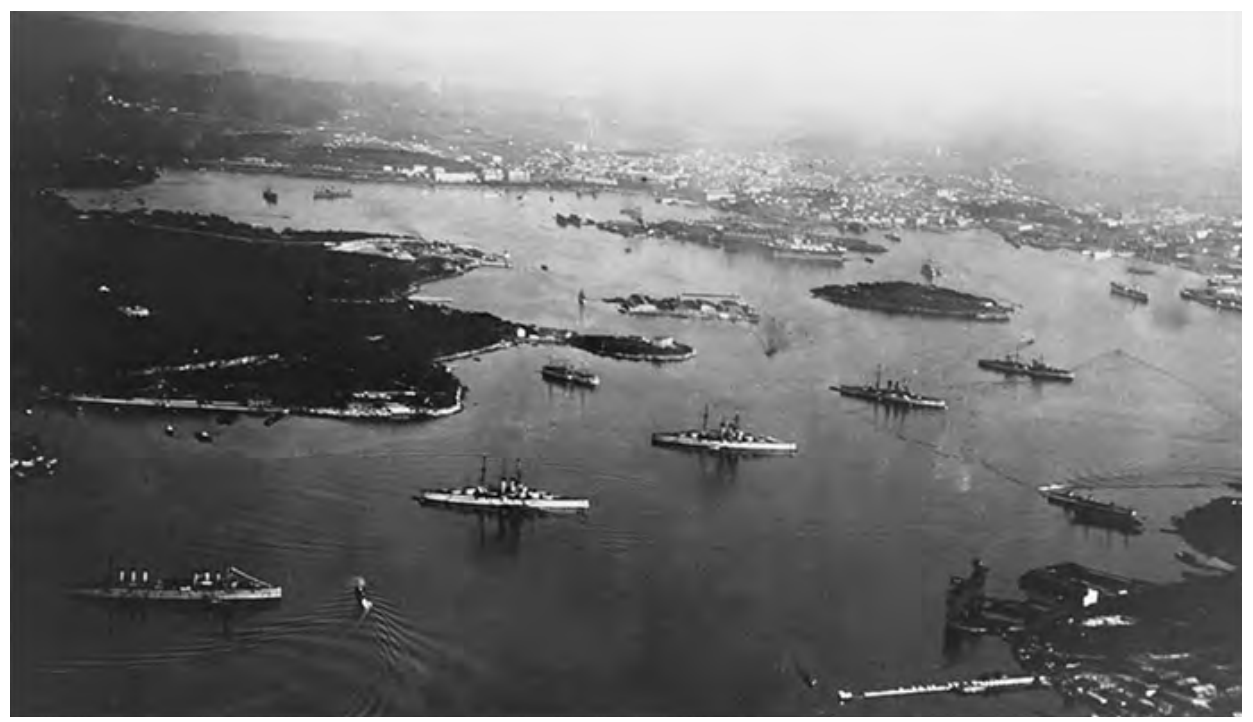

__ Figure 1: Pula's Harbor about 1918 (http://tehnika.Izmk.hr/vojna-brodogradnja-2/)

\section{PULA NAVAL FORTRESS}

Since the middle of the 19th century, Pula was the main naval base of the Austrian Navy and the core of the coastal sector of the fortification system stretching from the Premantura to Rovinj and Labin, within which the most significant and most numerous military buildings in the Pula area were built from 1813 to 1918. (*** 2003: 9) The fortification system of the Pula Naval Fortress was divided into three defensive rings and was built in three stages. In the first fortress system building stage, which lasted approximately from 1823 to $1870,(* * * 2011$ : 9), the separate circular forts were built, also known as artillery towers. The second fortress system building stage, which lasted approximately from 1872 to 1889 , was marked by the expansion of construction outside the medieval city walls and the construction of typical circular or segment forts with inner courtyard, artillery batteries, field fortifications and "Pula towers". (Krizmanić, 2009: 42) The third stage, which lasted from 1892 to 1918 , was marked by technological progress after the invention of the brisant grenade in 1885, which enable the change of the defence system. The circular forts have lost their importance, and new type of the elongated polygonal forts buried in the ground have appeared. Along with the upgrading of the existing ones, new fortifications were built, placed strategically at the most important points in the distance of five to eight kilometres from Pula. The Pula Naval Fortress system is characterised by rationality, economy and utilitarianism. The fortifications of the Pula Naval Fortress were built in accordance with the logic and capabilities of the then war technology. They were adapted to the terrain, exploiting the potentials and natural features of each site. Each fortification consists of a built and "unbuilt" part. The construction of the fortification is complemented with the protective 
moats and camouflaged greenery, creating a unique architectural-landscape unit. In 1917, the fortification system of the Pula Naval Fortress, with about 220 sites, occupied the area of approximately 700 square kilometres (mainland with islands), where around 42,500 officers and soldiers were stationed. The Pula Naval Fortress retained its defence function until the Second World War. From 1947 the fortifications was the property of the Yugoslav Army and since 1991 they belong to the Croatian Army, although have been gradually abandoned. Today, most of the fortifications of the Pula Naval Fortress are neglected or abandoned partly due to the demilitarization of the Pula Bay (Strenja, Perčić, Mladinov, Jurcan, 2006: 2) and partly because of the lack of a long-term sustainable strategy of their use and protection that would enable the development of affirmative programs, plans and projects for adaptation and revitalization.

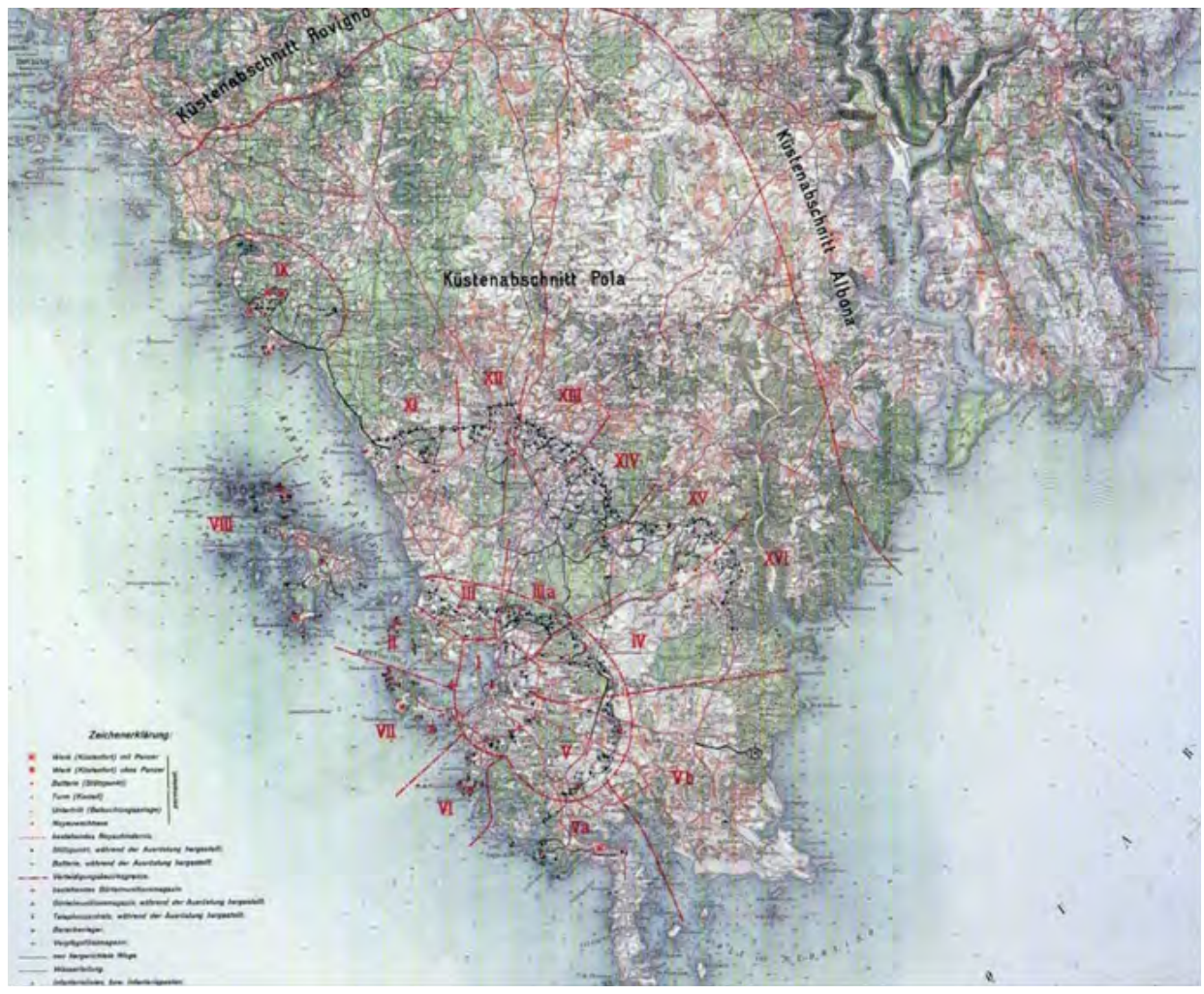

_ Figure 2: Pula Naval Fortress with 19 defensive sectors, 1917 (Krizmanić, 2009: 150-151)

\section{PULA NAVAL FORTRESS IN THE SPATIAL PLANNING DOCUMENTS OF THE PULA AREA}

Detection, valorisation and protection of fortifications of the Pula Naval Fortress has been gradually introduced into the spatial planning documents of the Pula and neighbouring areas where the buildings, sets and systems of the Pula Naval Fortress are located. The 1966 General Urban Plan of the City of Pula defined the military areas as special zones, but the fortifications of the Pula Naval Fortress were not evaluated as cultural monuments. During the 1960s, the Yugoslav Army began devastating the fortifications of the Pula Naval Fortress, which were used as warehouses or were neglected and therefore ruined. The 1983 General Urban Plan of the City of Pula defines six categories of architectural heritage. Fortification and similar buildings were in the group " $D$ ": important strategic points in the Pula defence system - the main naval base of the Austro-Hungarian Empire, 
built in the period from the first half of the 19th century to the First World War. The 1992 Urban Development Plan "Old Town of Pula" defined an integral process of work on existing buildings of the architectural heritage, including the development of documentation of the existing situation and the study of spatial and historical development of buildings. In 2006 in the Spatial Planning of the City of Pula with a view to the preservation and revitalization of abandoned and neglected Austrian fortifications and artillery battery in the wider city area, their purposes (with possible use for activities primarily in the field of culture, education, representative use in the function of management, city documentation archives or similar activities, fine crafts, trade and catering, tourism, recreation and sports or other appropriate activities) are determined. (*** 2006: 620) In the General Urban Plan of the City of Pula from 2008, the fortifications and artillery battery of the Pula Naval Fortress are mainly classified as category " 1 " among the buildings or structures of exceptional monumental values of wider regional and state importance, which must be absolutely preserved and renewed by methods of scientific processing and conservation principles, where the demolition of only inadequate contemporary construction additions is allowed. (*** 2008: 239) In the Spatial Plan of the National Park "Brijuni", the theme of conversion of Austrian fortifications was also discussed. For example, for the Fort Tegetthoff the plan proposes museum-exhibition purposes, as well as the creation of a program of tours and study of Austrian fortifications with accompanying manifestations. (*** 2001: 61)

\section{CONVERSION OF FORTIFICATIONS OF PULA NAVAL FORTRESS}

Today the fortifications of the Pula Naval Fortresses are not used and therefore constitute a facility void system that need to be reallocated and affirmed as a new facility potential that suits local or regional needs. In this sense, this "facility void network" can be viewed by quadrants, linear or dotted, networking zones, connecting groups of buildings or concentrating on individual structures, depending on conditions and needs. The process of introducing new facilities and networking fortifications of the Pula Naval Fortress would potentially encourage the inversion of the defensive function of rejection into its opposite, in the function of visitor attraction. (Mlinar, Prižmić, 2013: 3738) In this process, the most appropriate method would be the adaptation and revitalization method, which proved to be in practice one of the most effective ways of protecting, restoring, preserving and presenting the architectural heritage. (Marasović, 1985: 128)

The process of conversion of the fortifications of the Pula Naval Fortress has begun with the reuse of the coastal armored polygonal Fort Verudella. In the 1970's the fort was used for catering purposes, and in the 1980s it became a landfill and garbage dump. The 2002 fort was taken by Aquarium Pula. Along with the aquarium, the fort becomes part of the cultural-tourist offer as a place for various events, such as exhibitions, concerts and sports competitions. Since 2001 during the summer the coastal armored polygonal Fort Brioni Minor has been used as a stage by the Ulysses Theater. Conversion of the coastal Fort Punta Christo is an example of a civic initiative of youth that has voluntarily taken care of it since 2001 and has been organizing concerts and music festivals since 2003. The circular-shape Fort San Giorgio type "Pula tower" was determined for the conversion into the Croatian Restoration Workshop of the Restoration Institute - Department of Pula in 2007. (*** 2009) In this case, it is questionable to place a demanding new facility into a protected building with limited space. The complexity of the transformation of the Fort San Giorgio is evident in the conservative aspiration to maintain the original structure of the fort, which almost prevents the technical requirements for restoration work such as the necessary room size, ventilation, lighting and other installations in the rooms. The mentioned examples of forts Verudella, Brioni Minor, Punta Christo and San Giorgio have not been realized by integral consideration and planning conversion of fortifications of the Pula Naval Fortress but are more or less successful exceptions that should not become a model for partial conversions of individual fortifications of the Pula Naval Fortress. Despite the individual examples of conversion and use of fortifications, only a comprehensively considered strategy as well as the program, plan and projects will preserve and highlight the values and potentials of the exceptional fortification system of the Pula Naval Fortress. 


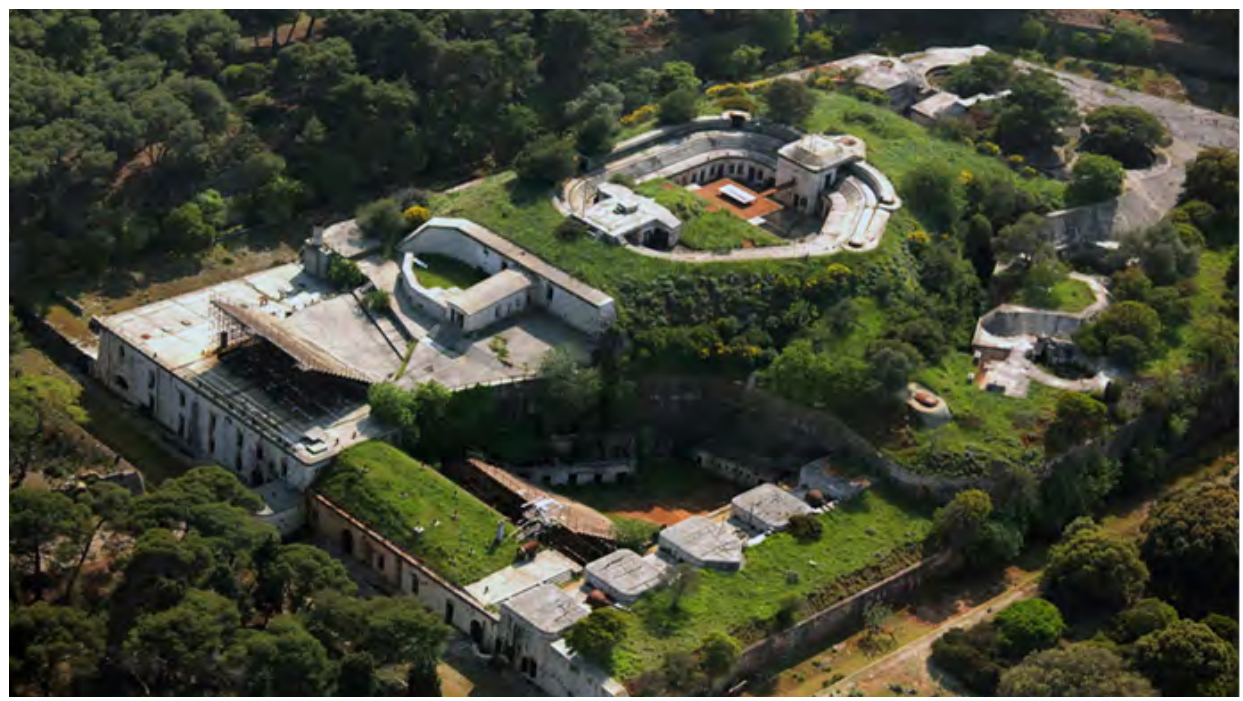

_ Figure 3: Auditoriums and stages of Theatre Ulysses in the Fort Brioni Minor (http:// http://kamenmost.viviss.si/brijuni/)

\section{CONCLUSIONS}

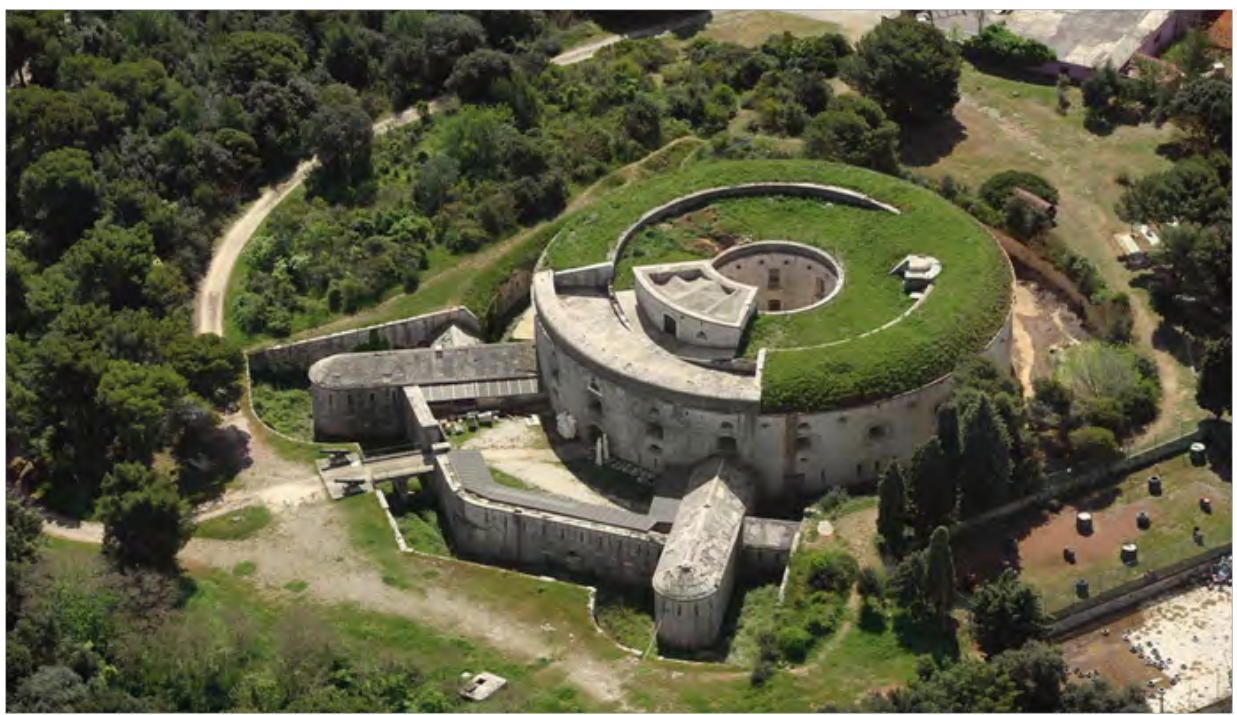

_ Figure 4: The Fort Bourguignon on Verudela (https://www.istria-culture.com/utvrda-punta-christo-i143)

The system of the former Pula Naval Fortress is part of the recent Pula architectural heritage that needs to be properly integrated into the strategy of the future development of the city and its region. The future of the former Pula Naval Fortress can be ensured by integral considering and emphasising its potential, as well as its quality and appropriate functional conversion, with the protection, restoration, preservation and presentation of all important urban and architectural features. By re- 
vitalizing the fortifications of the Pula Naval Fortress, their stratification and flexibility would be emphasized so that the former defence function remains visible in the structure, while the imported functions enable new dynamics of usage. Thereby fortifications should be observed throughout the whole of the Pula Naval Fortress, taking into account the purpose and facilities in the environment, as well as the natural and architectural particularities of each fortification with the aim of complementing natural, historical and cultural values and tourist offerings. The prerequisite for conversion of the fortifications of the Pula Naval Fortress is a detailed research work that results in a system comprehensive study and expert basis for each individual fortification, taking into account its ambivalent, typological and architectural features as well as its immediate and wider environment. By highlighting the image, identity and quality of the Pula Naval Fortress its further decay can be prevented, as well as encouraged its renewal, ensured maintenance and provided eventual additional income.

\section{REFERENCES}

- Hrvatska tehnička enciklopedija. 2016. "Vojna brodogradnja." Last modified December 3. Accessed December 20, 2018. http://tehnika.Izmk.hr/vojna-brodogradnja-2/

- Istra Culture. 2019. "Utvrad Punta Cristo." Accessed February 28, 2019. https://www.istria-culture. com/utvrda-punta-christo-i143

_ Kamen-Most. 2019. “Brijuni" Accessed February 28, 2019. http://kamen-most.viviss.si/brijuni/

- Krizmanić, Attilio. 2009. Pulska kruna. Pula: Čakavski sabor.

_ Marasović, Tomislav. 1985. Aktivni pristup graditeljskom nasljeđu. Split: Sveučilište u Splitu - Filozofski fakultet u Zadru - OOUR prirodoslovno-matematičkih znanosti i studija odgojnih područja u Splitu, Društvo konzervatora Hrvatske - Zagreb, Arhitektonski fakultet Sveučilišta u Zagrebu - Postidplomski studij graditeljskog nasljeđa u Splitu.

_ Marković, Jagoda. 2006. "Pula - K. u. K. slika grada."Radovi Instituta za povijest umjetnosti, no. 30: 215-228.

- Milić, Bruno. 1994. Razvoj grada kroz stoljeća I: Prapovijest - antika. Zagreb: Školska knjiga.

- Milić, Bruno. 1995. Razvoj grada kroz stoljeća II: Srednji vijek. Zagreb: Školska knjiga.

- Mlinar, Ivan, and Ela Prižmić 2013. "Afirmacija sustava austrijske Pomorske tvrđave Pula." Korak u prostor, no. 3/43: 36-39.

_- Regan, Krešimir, and Branko Nadilo. 20013. "Utvrde Pule i okolice (II. dio)." Građevinar, no. 3: 283-296.

- Strenja, Edna, and Marko Perčić, Jerolim Mladinov, Emil Jurcan. 2006. Katarina 06, otvaranje pulske obale. Zagreb: UPI-2M PLUS.

- Trogrlić, Marko, and Željko Stepanić. 2007. "Pula kao Austu-Ugarska ratna luka." Školski vjesnik, no. 1-2, 17-30.

_ *** 2001. "Prostorni plan Nacionalnog parka "Brijuni"." Narodne novine, no. 45: 1284-1309.

_ *** 2003. Bilten međunarodne ljetne radionice arhitekture Mali Brijun 2001. i 2002. Zagreb: Republika Hrvatska, Ministarstvo kulture, Uprava za zaštitu kulturne baštine.

_ *** 2006. "Prostorni plan uređenja grada Pule." Službene novine Grada Pule, no. 12: 616-660.

_ *** 2008. "Generalnoi urbanistički plan grada Pule." Službene novine Grada Pule, no. 5a: 193-256.

_ *** 2009. Utvrda Sv. Juraja u Puli - Studija rješenja. Zagreb: Hrvatski restauratorski zavod, Služba za nepokretnu baštinu.

_ *** 2011. Bilten međunarodne ljetne radionice arhitekture Barbariga 2005. Zagreb: Republika Hrvatska, Ministarstvo kulture, Uprava za zaštitu kulturne baštine. 